\title{
Studies on the Structure of Ribosomal Ribonucleic Acid from Normal and Tumour Tissues
}

\author{
VI. Dissociation Properties \\ H. Bielka and G. Lutsch
}

Institute for Cellphysiology of the German Academy of Sciences of Berlin, Berlin-Buch

(Z. Naturforschg. 22 b, 1035-1043 [1967] ; eingegangen am 19. Dezember 1966)

\begin{abstract}
The dissociation properties of ribosomal RNA from liver and hepatoma were found to be dependent upon the temperature, ionic strength and cationic valency of the solvent. On increasing the temperature the $p_{\mathrm{K}}$ values of the $\mathrm{N}^{1} \mathrm{H}-\mathrm{C}^{6}=0$ and $\mathrm{N}^{1}=\mathrm{C}^{6}-\mathrm{NH}_{2}$ groups of nucleobases were displaced towards neutrality due to the thermal cleavage of H-bridge linkages. Consequently, as the temperature is increased the nucleic acids bind increasingly more equivalents of acid or alkali. On forward- and back-titration hysteresis is observed in the acid $p_{\mathrm{H}}$ range and the degree of hysteresis is found to decrease as the temperature is increased. Increasing the ionic strength of monovalent cations from $\mu=0.005$ to $0.05 \mathrm{Na}^{\oplus}$ leads to a reduced binding of equivalents of acid and alkali

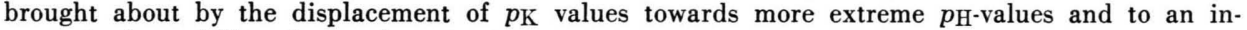
crease in the stability of secondary structure.

Bivalent cations exert a stronger stabilizing effect on the molecular conformation of nucleic acids than monovalent cations of equal ionic strength. The more pronounced displacement of the $p_{\mathrm{K}}$ values of ionizable groups on titration from $p_{\mathrm{H}} 7$ to $p_{\mathrm{H}} 3$ may be attributed to the additional action of bivalent cations as chelate formers.

Significant differences in the acid-base properties of ribosomal RNA from liver and hepatoma were observed especially at low temperatures and high ionic strength. At $5^{\circ} \mathrm{C}$ and $\mu=0.1 \mathrm{NaCl}$ less equivalents of acid and alkali are bound by hepatoma RNA than by liver RNA due to a lower degree of dissociation particularly of the $\mathrm{N}^{1}=\mathrm{C}^{6}-\mathrm{NH}_{2}$ and $\mathrm{N}^{1} \mathrm{H}-\mathrm{C}^{6}=0$ groups.
\end{abstract}

The acid-base properties of nucleic acids are different from the behaviour of a simple polyelectrolyte. The ionization of bases is largely dependent upon secondary structure i.e. upon the form and stability of the conformation of polynucleotides. Changes in the conformation and interaction of the bases of nucleic acids are reflected in their dissociation properties.

In previous experiments ${ }^{1-3}$ we described differences in the optical behaviour of ribosomal RNA from liver and hepatoma, particularly increased $T_{\mathrm{m}}$. values of ribosomal RNA from hepatomas on thermal denaturation under different ionic conditions ${ }^{2}$ and in the presence of urea ${ }^{3}$. In view of the effect of secondary structure upon the degree of ionization i. e. upon the dissociation constants of the base residues, it is considered that studies on the dissociation properties of nucleic acids under different ionic conditions and at different temperatures are suitable to provide information about their structure and conformational changes.

1 H. Bielka, I. Schneiders, and A. Henske, Acta biol. med. german. 13, 13 [1964].

2 H. Bielka, I. Junghahn, and I. Schneiders, Z. Naturforschg. 19 b, 1121 [1964].
Hence, studies have been carried out to investigate the acid-base properties of ribosomal RNA from liver and hepatoma and the effect of ionic strength, ionic valency and temperature upon the dissociation properties, in order to gain further information about the conformation of ribosomal RNA and its stability.

\section{Experimental}

\section{Material}

High-molecular-weight ribosomal RNA obtained from normal rat liver (Wistar strain) and from transplantable hepatocellular carcinomas of rats of the same strain primarily induced by feeding diethylnitrosoamine was used in these experiments.

The RNA preparations were polydisperse having sedimentation constants of $S_{20, \mathrm{~W}}^{0}=30.8 \pm 0.48$ and $17.4 \pm 0.37$ for liver and $31.4 \pm 0.29$ and $17.1 \pm 0.14$ for hepatoma.

In a sucrose gradient $(5-20 \%)$ ribosomal RNA was found to sediment in two homogenous fractions. 3 I. Junghahn and H. Bielka, Naturwissenschaften 52, 62
[1965]. 


\section{Preparation of Ribosomal RNA}

The tissues were homogenized in $0.1 \mathrm{M} \mathrm{NaCl} / 0.01 \mathrm{M}$ Tris-buffer $\left(p_{\mathrm{H}} 7.2\right)$ at $0{ }^{\circ} \mathrm{C}$ in a Potter homogenizer fitted with a Teflon pestle. Microsomes and ribosomes were sedimented from the $10000 \mathrm{~g}$-postmitochondrial supernatant by ultracentrifugation (Spinco L 2, $105000 \mathrm{~g}, 60$ minutes at $\left.0{ }^{\circ} \mathrm{C}\right)$. The RNA was isolated from the resuspended pellet by stirring with dodecyl sulfate $(0.1 \%)$ and water-saturated redistilled phenol ( $p_{\mathrm{H}}$ 6.7) for 30 minutes at $20^{\circ} \mathrm{C}$. Denatured proteins were separated by centrifugation at $12000 \mathrm{~g}$ for 10 minutes. The RNA was precipitated from the aqueous phase after addition of potassium acetate at a final concentration of $2 \%$ with 2.5 volumes of $96 \%$ ethanol at $0^{\circ} \mathrm{C}$. At a concentration of $1 \mathrm{mg} / \mathrm{ml}$ the RNA precipitate was transferred to the solutions used for titration and dialyzed against the corresponding solvent for 24 hours at $0{ }^{\circ} \mathrm{C}$. A stream of purified nitrogen was passed through the dialysis bath.

\section{Spectrophotometric Measurements}

The RNA-concentrations were determined by UV absorbancy measurements at $260 \mathrm{~nm}$ with an extinction coefficient of $E_{260}^{10 / 0}=210$ and $\varepsilon(\mathrm{p})=6.800$ in $0.1 \mathrm{M}$ $\mathrm{NaCl} / 0.01 \mathrm{M}$ Trisbuffer $p_{\mathrm{H}} 7.2$ at $20{ }^{\circ} \mathrm{C}$.

\section{Analytical Ultracentrifugation}

A Spinco Model E Ultracentrifuge with U.V. absorption optics was used for sedimentation analyses. Records were made at 2 minutes' intervals after reaching maximum speed (= $42040 \mathrm{rev} . / \mathrm{min}$.). The temperature was $4{ }^{\circ} \mathrm{C}$. Densitometric analyses were carried out in a Beckman Analytrol densitometer RB. Sedimentation coefficients were corrected to $20^{\circ} \mathrm{C}$ for viscosity and density.

Nucleic acids were dissolved in $0.1 \mathrm{M} \mathrm{NaCl} / 0.01 \mathrm{M}$ Tris-buffer ( $\left.p_{\mathrm{H}} 7.2\right)$ at concentrations of 20 to $80 \mu \mathrm{g} / \mathrm{ml}$.

\section{Electrometric Titrations}

Titrations were carried out with a titration device supplied by the firm "Radiometer". The device consists of the titrator TTT 1 ( $p_{\mathrm{H}}$ meter), the titragrapher SBR 2 (recorder), a micrometer syringe SBU 1 and a mictrotitration device TTA 31. A calomel electrode $\mathrm{K} 4012$ and a glass electrode $\mathrm{G} 2222 \mathrm{C}$ covering the $p_{\mathrm{H}^{-}}$ range $0-12$ were used as measuring devices. Errors in the electrodes were corrected for $p_{\mathrm{H}}>11$ at $\mu=0.01 \mathrm{Na}^{\oplus}$ and for $p_{\text {H }}>9.5$ at $\mu=0.1 \mathrm{Na}^{\oplus}$. The accuracy of the titrator was to within $0.02-0.05$ $p_{\mathrm{H}}$ units and $\pm 0.2^{\circ} \mathrm{C}$.

Calibration of the $p_{\mathrm{H}}$ meter was carried out with a phthalate buffer $p_{\mathrm{H}} 4.0$, a phosphate buffer $p_{\mathrm{H}} 6.88$, and a borate buffer $p_{\mathrm{H}} 9.22$, at $20^{\circ} \mathrm{C}$. For calibration at temperatures other than $20^{\circ} \mathrm{C}$, the same buffer solutions were employed and the values used for the cor-

4 R. A. Cox and U. Z. Littauer, Biochim. biophysica Acta [Amsterdam] 72, 188 [1963]. responding temperatures were those indicated by the National Bureau of Standards (USA). The titration vessel was constructed of polyethylene and was flushed during the experiment with purified nitrogen.

Titrations were carried out with $0.05 \mathrm{~N} \mathrm{HCl}$ and $0.05 \mathrm{~N} \mathrm{NaOH}$ with stirring. In each case a carbonatefree sodium hydroxide solution was freshly prepared by dilution of a stock solution. The concentration of RNA solutions was $1 \mathrm{mg} / \mathrm{ml}$. According to Cox and LitTauer $^{4}$ the titration properties are independent of RNA concentration over the range $0.5-4 \mathrm{mg} \mathrm{RNA} / \mathrm{ml}$. In each case volumes of $2 \mathrm{ml}$ were titrated and one blank solution was titrated on each titration cycle. The titration values of RNA solutions were corrected against the blank values. Additionally, the "water correction" by the method of JORDAN and TAYLOR ${ }^{5}$ was carried out below $p_{\mathrm{H}} 4$ and above $p_{\mathrm{H}} 10$ according to the following equation

$$
V_{\mathrm{s}}^{\prime}(\text { corr. })=\frac{V_{\mathrm{s}^{\prime}} \cdot V_{\mathrm{g}}}{V_{\mathrm{g}^{\prime}}}, \text { where } V_{\mathrm{g}}=V_{\mathrm{A}}+V_{\mathrm{s}} .
$$

( $V_{\mathrm{g}}=$ total volume of RNA solution; $V_{\mathrm{g}}{ }^{\prime}=$ total volume of blank solution; $V_{\mathrm{A}}=$ initial volume; $V_{\mathrm{s}}=$ quantity of acid or alkali added to the RNA solution; $V_{\mathrm{s}}^{\prime}=$ quantity of acid or alkali added to the blank solution).

The true difference between RNA solution and blank solution can be derived from

$$
V_{\mathrm{s}}-V_{\mathrm{s}}{ }^{\prime} \text { (corr.). }
$$

The experimental results described are represented as curves derived from the mean values of a number of separate titrations. Data denoting the ratio - number of preparations tested/number of separate titrations are given in parentheses in the legends of the figures e. g. (3/6). A complete titration cycle consists of titration with acid from $p_{\mathrm{H}} 7$ to $p_{\mathrm{H}} 2.5$, subsequent titration with alkali to $p_{\mathrm{H}} 11.5$ and backtitration with acid to neutrality.

\section{Determination of Phosphorus}

Phosphorus was determined by the method of BEErenblum and Chain and Fiske-Subbarow.

\section{Results}

\section{Dependence of Acid-Base Properties upon Tempera- ture at Constant Ionic Strength}

Titrations were carried out in $0.1 \mathrm{M} \mathrm{NaCl}$ at $5{ }^{\circ} \mathrm{C}$, $20{ }^{\circ} \mathrm{C}$ and $50{ }^{\circ} \mathrm{C}$. The results of the experiments described below show that within definite $p_{\mathrm{H}}$ ranges the dissociation behaviour of nucleic acids is dependent upon temperature.

At $5^{\circ}$ the titration curve for ribosomal RNA from liver is found to be reversible within the ex-

5 D. O. Jordan and H. F. W. TAylor, J. chem. Soc. [London] 1946, 994. 

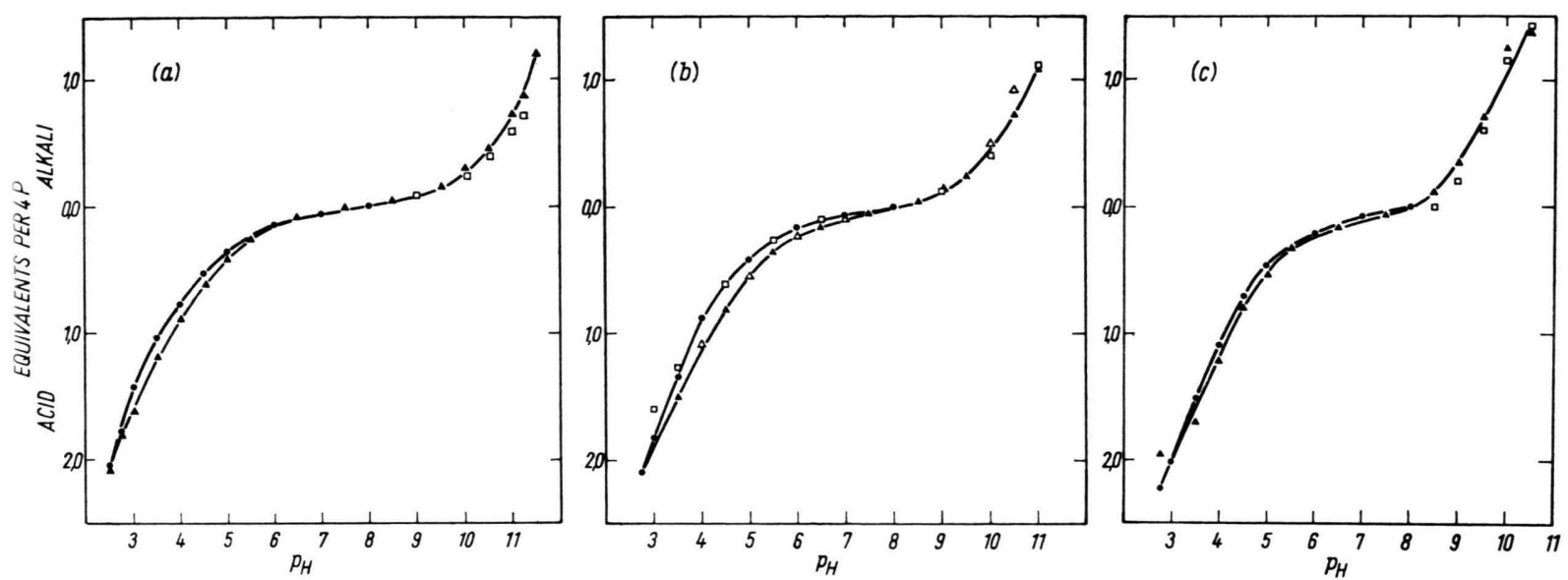

Fig. 1. Titration of ribosomal RNA from rat liver in $0,1 \mathrm{M} \mathrm{NaCl-solution.} \mathrm{(a)} \mathrm{at} 5^{\circ}$, (b) at $20^{\circ}$, (c) at $50^{\circ}$. with acid from $p_{\mathrm{H}} 8$ to $p_{\mathrm{H}} 2.75 ; \boldsymbol{\Delta}$ titration with alkali from $p_{\mathrm{H}} 2.75$ to $p_{\mathrm{H}} 11.25 ; \square$ titration with acid from $p_{\mathrm{H}} 11.25$ to $p_{\mathrm{H}} 2.75 ; \triangle$ a second titration with alkali from $p_{\mathrm{H}} 2.75$ to $p_{\mathrm{H}}$ 11.25. Mean values of 6 separate titrations with 3 different RNA-preparations $=3 / 6$.

perimental error over the alkaline range (figure 1 a). At $p_{\mathrm{H}} 11.3550 \%$ of the titratable $\mathrm{N}^{1} \mathrm{H}-\mathrm{C}^{6}=\mathrm{O}$ groups are ionized. In the acid $p_{\mathrm{H}}$ range $50 \%$ of the titratable groups dissociate within the range to $p_{\mathrm{H}}$ 3.54. After titration to $p_{\mathrm{H}} 2.5$ hysteresis is observed on back-titration. More equivalents of acid are bound on back-titration than on forward-titration, the difference at $p_{\mathrm{H}} 4$ being 0.13 equivalents per 4 P-gramatoms (table 1).

Curves for ribosomal RNA from liver and hepatoma found on forward- and back-titration at $5^{\circ}$ are represented in figure 2 a. Essentially, both types of RNA reveal the same pattern although certain quantitative differences are observed indicating that less equivalents of acid or alkali are bound by ribosomal RNA from hepatoma. Consequently, the $p_{\mathrm{K}}$ values of ionizable groups are displaced towards more extreme $p_{\mathrm{H}}$ values both in the alkaline and acid ranges of $p_{\mathrm{H}}$ (table 1). At $p_{\mathrm{H}} 2,75$ the difference between the two curves is -0.33 gram equivalents per $4 \mathrm{P}$-gramatoms. The difference is statistically significant $(p<0.01)$.

At $20^{\circ}$ the titration pattern was about the same as that at $5^{\circ}$ (figure $1 \mathrm{~b}$ ). Significant differences, however, are found with regard to the larger quantity of acid necessary for titration to $p_{\mathrm{H}} 2.5$ and the larger amount of alkali required for titration to $p_{\mathrm{H}}$ 11.25. In the alkaline range of $p_{\mathrm{H}}$ the curves found
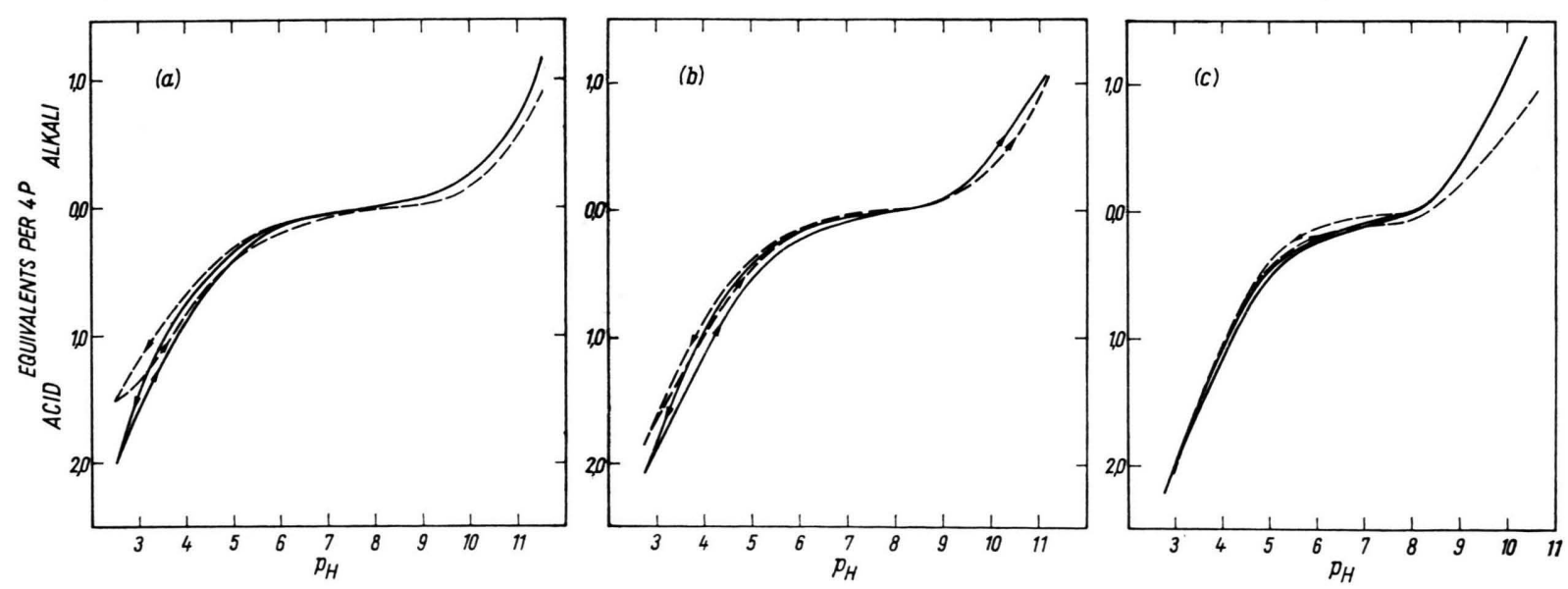

Fig. 2. Comparison of the titrations of ribosomal RNA from liver ( - ) and hepatoma (-- $)$ in $0.1 \mathrm{M}$ NaCl-solution. (a) at $5^{\circ}$, (b) at $20^{\circ}$, (c) at $50^{\circ}$. 


\begin{tabular}{|c|c|c|c|c|}
\hline $\begin{array}{l}\text { Experimental } \\
\text { conditions }\end{array}$ & & $\begin{array}{c}\mathrm{pH} \text { for } 50 \% \text { dissociation } \\
\text { in the }\end{array}$ & $\begin{array}{c}\text { Hysteresis } \\
\text { ( } \Delta \text { equivalents of } \\
\text { acid at } \mathrm{pH} 4 \text { on } \\
\text { forward and } \\
\text { back titration) }\end{array}$ & $\begin{array}{l}\text { Equivalents } \\
\text { of acid bound } \\
\text { per } 4 \text { P-gatoms } \\
\text { at pH } 2.75\end{array}$ \\
\hline $5^{\circ}$ Liver-RNA & 3.5 & 11.4 & 0.13 & 1.65 \\
\hline Hepatoma-RNA & 3.2 & 11.6 & 0.15 & 1.32 \\
\hline $20^{\circ}$ Liver-RNA & 3.9 & 10.8 & 0.25 & 2.00 \\
\hline Hepatoma-RNA & 3.8 & 11.1 & 0.15 & 1.85 \\
\hline $50^{\circ}$ Liver-RNA & 4.1 & 9.9 & 0.10 & 2.2 \\
\hline Hepatoma-RNA & 4.1 & 10.6 & 0 & 2.2 \\
\hline
\end{tabular}

Table I. Dissociation properties of rRNA from liver and hepatoma in $0.1 \mathrm{M} \mathrm{NaCl-solution} \mathrm{depending} \mathrm{upon} \mathrm{different} \mathrm{tempera-}$ tures.

ond forward- and back-titration are again reversible; at $p_{\mathrm{H}} 10.8450 \%$ of the $\mathrm{N}^{1} \mathrm{H}-\mathrm{C}^{6}=\mathrm{O}$ groups are dissociated. Hence, this value is about $0.6 p_{\mathrm{H}}$ units less than that obtained at $5{ }^{\circ} \mathrm{C}$.

In the acid range $50 \%$ of the titratable groups are already ionized at $p_{\mathrm{H}} 3.87$ (table 1 ). The degree of hysteresis observed at $p_{\mathrm{H}} 4$ is 0.25 equivalents per 4 P-gramatoms.

Furthermore, the measuring points of a second titration cycle with alkali from $p_{\mathrm{H}} 2.75$ to $p_{\mathrm{H}} 11.25$ are plotted in figure $1 \mathrm{~b}$. The shape of the second titration curve is coincident with that of the first cycle.

On comparing the titration curves of ribosomal RNA from liver and hepatoma represented in figure $2 \mathrm{~b}$ it will again be noticed that the curve for ribosomal RNA from hepatoma is displaced towards more extreme $p_{\mathrm{H}}$ values (table 1 ). At a temperature of $20^{\circ}$ less equivalents of acid are bound by ribosomal RNA from hepatoma than by ribosomal RNA from liver, particularly in the acid $p_{\mathrm{H}}$ range, but the differences (at $p_{\mathrm{H}} 2.75-0.15$ gram equivalents per $4 \mathrm{P}$-gramatoms) are not significant.

At $50^{\circ}$ (figure $1 \mathrm{c}$ ) more equivalents of acid are bound by RNA on titration to $p_{\mathrm{H}} 2.75$ than at $20{ }^{\circ} \mathrm{C}$. This is due to a further shift in the $p_{\mathrm{K}}$ values of ionizable groups. $50 \%$ of these groups are already ionized at $p_{\mathrm{H}} 4.1$. This indicates a displacement by $0,23 p_{\mathrm{H}}$ units compared with the values obtained at $20^{\circ}$. Moreover, a decrease in hysteresis is observed in the acid range of $p_{\mathrm{H}}$. The difference between forward- and back-titration at $p_{\mathrm{H}} 4$ is 0.1 gram-equivalent per $4 \mathrm{P}$-gramatoms. Over the alkaline range of $p_{\mathrm{H}}$ the titration curves are again found to be reversible, within the experimental error although at $50^{\circ}$ significantly more equivalents of alkali are bound by ribosomal RNA than at $20^{\circ} \mathrm{C}$.
$50 \%$ of the $\mathrm{N}^{1} \mathrm{H}-\mathrm{C}^{6}=0$ groups are dissociated at $p_{\mathrm{H}}$ 9.9. Hence, this value is $0.94 p_{\mathrm{H}}$ unit less than that found at $20^{\circ} \mathrm{C}$ and 1.45 units less than that at $5{ }^{\circ} \mathrm{C}$. A comparison of the titration curves for ribosomal RNA from liver and hepatoma shown in figure $2 \mathrm{c}$ reveals that no difference in titration properties are observed at $50{ }^{\circ} \mathrm{C}$, particulary in the acid range of $p_{\mathrm{H}}$. On forward-titration to $p_{\mathrm{H}} 2.75$ no differences in acid consumption are noted.
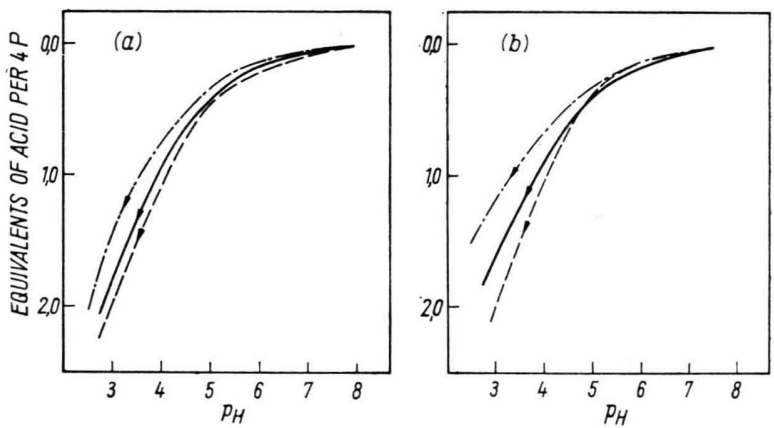

Fig. 3. Titration of RNA from liver (a) and hepatoma (b) at different temperatures in $0.1 \mathrm{M} \mathrm{NaCl}$-solution. $-\cdot-\cdot-$ at $5^{\circ}, \longrightarrow$ at $20^{\circ},---$ at $50^{\circ}$.

Consequently, the acid-base properties of ribosomal RNA are largely dependent on temperature (figure 3). With increasing temperature more equivalents of acid and alkali are bound by RNA within a particular $p_{\mathrm{H}}$ range. In the acid range of $p_{\mathrm{H}}$ the difference is found to be greatest between $p_{\mathrm{H}} 4.8$ and 2.75 especially when the temperature is raised from $5^{\circ}$ to $20^{\circ}$. Conformational changes brought about by changes in temperature are mainly observed below $p_{\mathrm{H}} 4.8$ and, in the alkaline range, above $p_{\mathrm{H}}$ 8.5. With increasing temperature, particularly with a rise in temperature from $20^{\circ} \mathrm{C}$ to $50{ }^{\circ} \mathrm{C}$ the degree of hysteresis is diminished within the acid $p_{\mathrm{H}}$ range. Simultaneously, the $p_{\mathrm{K}}$ values 
of ionizable groups are displaced towards neutrality (table 1).

Dissociation due to change in temperature occurs at $p_{\mathrm{H}}<5.5$ and at $p_{\mathrm{H}}>8$ while dissociation over the range $p_{\mathrm{H}} 5.5-8$ is largely independent of changes in temperature.

The experimental results show that increasing temperatures lead to a higher sensitivity of the helical structures of RNA to extreme $p_{\mathrm{H}}$ values so that at higher temperatures a rupture of $\mathrm{H}$-bonds will already take place at lower $\mathrm{H}^{\oplus}$-concentrations. The dependence of dissociation properties upon temperature is more pronounced in ribosomal RNA from hepatoma than in ribosomal RNA from liver (figure $3)$. On comparing the curves presented in figures $2 \mathrm{a}-\mathrm{c}$ and figures $3 \mathrm{a}$ and $3 \mathrm{~b}$ it will be noticed that the titration properties of RNA from liver and hepatoma are particularly different from each other in the low temperature range whereas at $50^{\circ}$ no differences are demonstrable.
Dependence of Acid-Base Properties upon Ionic Strength at Constant Temperature

Titrations were performed in solutions of RNA in $0.1 \mathrm{M}$ and $0.01 \mathrm{M} \mathrm{NaCl}$ at $20^{\circ} \mathrm{C}$.

On comparing the titration curves for ribosomal liver RNA derived from titration in $0.1 \mathrm{M}$ (figure $4 \mathrm{a}$ ) and $0.01 \mathrm{M} \mathrm{NaCl}$ solution (figure $4 \mathrm{~b}$ ) it was found that more equivalents of acid were bound by RNA in $0.01 \mathrm{M} \mathrm{NaCl}$ solution than in $0.1 \mathrm{M} \mathrm{NaCl}$ solution. Changes in molecular configuration due to a decrease in ionic strength from $\mu=0.1$ to $\mu=$ 0.01 are already observed below a $p_{\mathrm{H}}$ of 5.5 . If the ionic strength is increased from $\mu=0.01$ to 0.1 the acid branch of the titration curve is displaced by about $-0.5 p_{\text {H }}$ units (table 2 ) i. e. from $p_{\text {H }} 4.4$ to $p_{\mathrm{H}} 3.9$ relative to the $50 \%$-dissociation of groups titratable over this $p_{\mathrm{H}}$ range. Furthermore, it is apparent from titration in $0.01 \mathrm{M} \mathrm{NaCl}$ solution that the degree of hysteresis observed on forward- and
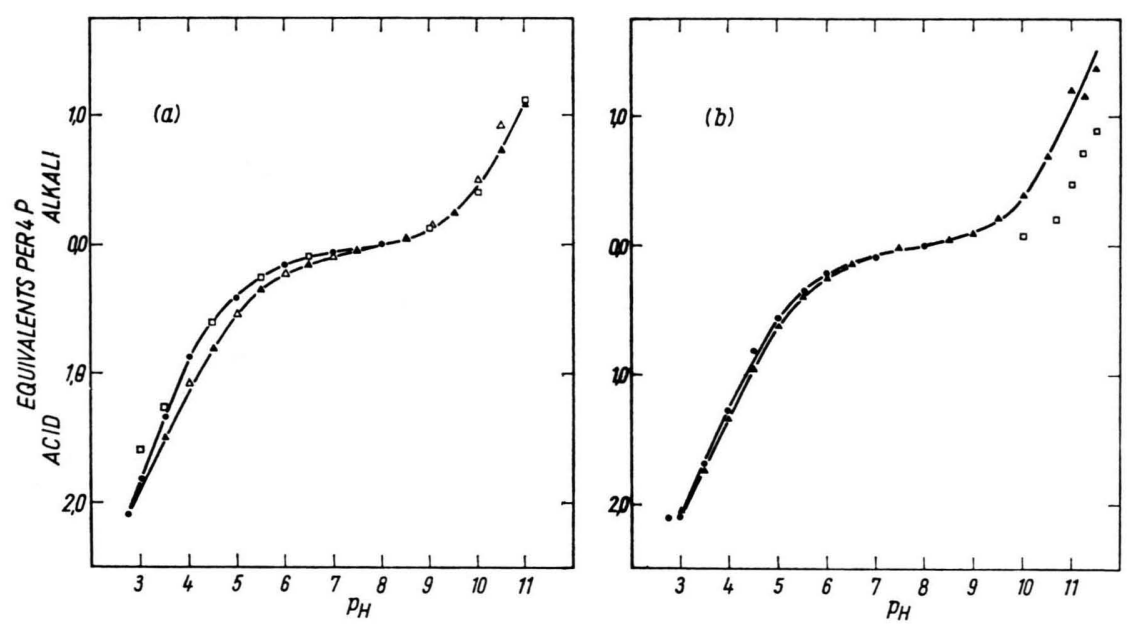

Fig. 4. Titration of liver-rRNA at $20^{\circ}$ in (a) $0.1 \mathrm{M} \mathrm{NaCl}$-solution and (b) $0.01 \mathrm{M} \mathrm{NaCl}$-solution. $3 / 6$ in every experiment. $\bullet, \Delta, \triangle, \square$ the same as in fig. 1 .

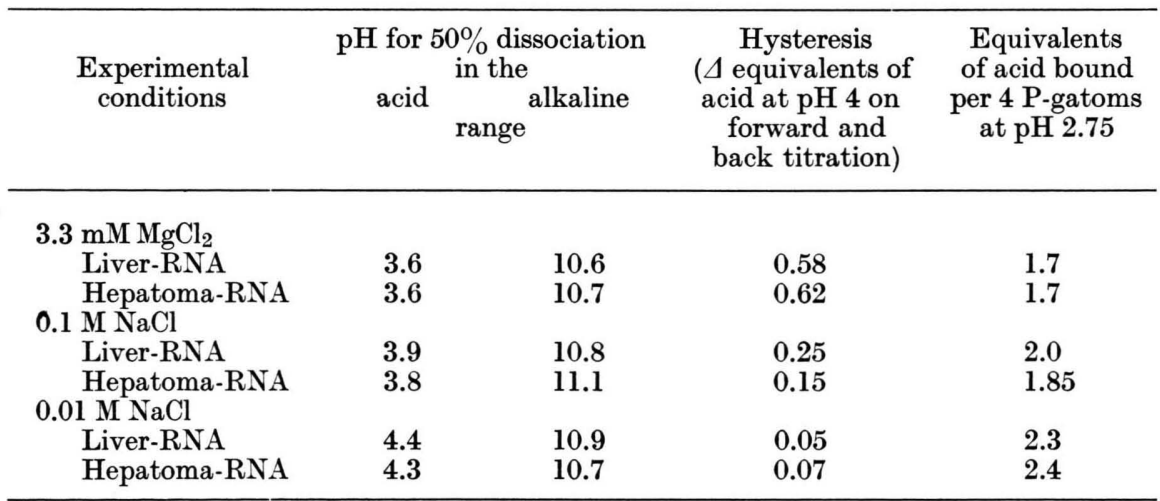

Table II. Dissociation properties of rRNA from liver and hepatoma at $20^{\circ}$ depending upon strength and valency of cations 

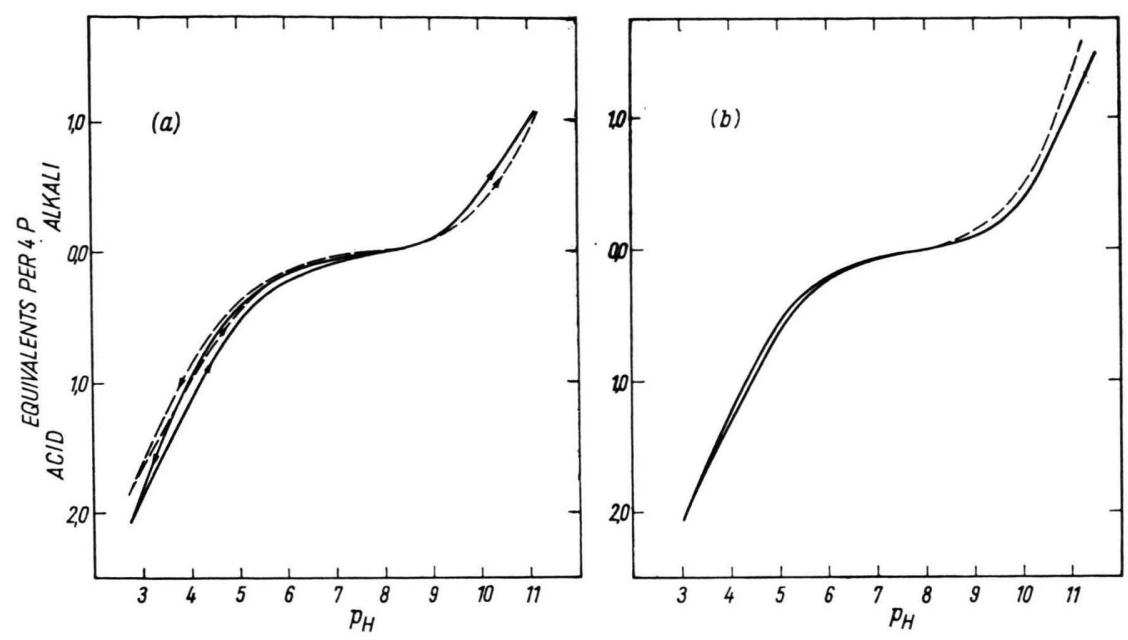

Fig. 5. Comparison of the titrations of ribosomal RNA from liver (-) and hepatoma $(---)$ at $20^{\circ}$ in (a) $0.1 \mathrm{M}$ $\mathrm{NaCl}$-solution, (b) $0.01 \mathrm{M} \mathrm{NaCl}$ solution. back-titration is considerably less than in $0.1 \mathrm{M}$ $\mathrm{NaCl}$ solution. In $0.1 \mathrm{M} \mathrm{NaCl}$ solution a difference of 0.25 gram-equivalents per 4 P-gramatoms was found at $p_{H} 4$ whereas in $0.01 \mathrm{M} \mathrm{NaCl}$ solution the difference found on forward- and back-titration at $p_{\mathrm{H}} 4$ amounts to only about 0.05 equivalents per 4 phosphorus gramatoms.

Contrary to the behaviour of ribosomal RNA from liver and hepatoma in $0.1 \mathrm{M} \mathrm{NaCl}$ solution (figure $5 \mathrm{a}$ ) no difference in the acid-base properties over the acid $p_{\mathrm{H}}$ range was found in $0.01 \mathrm{M}$ $\mathrm{NaCl}$ solution (figure $5 \mathrm{~b}$ ).

\section{Acid-Base Properties in the Presence of Mg-Ions}

The RNA used in these experiments was dissolved in $3.3 \mathrm{mM} \mathrm{MgCl}_{2}$ solution; titrations were carried out at $20^{\circ} \mathrm{C}$. The titration properties of ribosomal

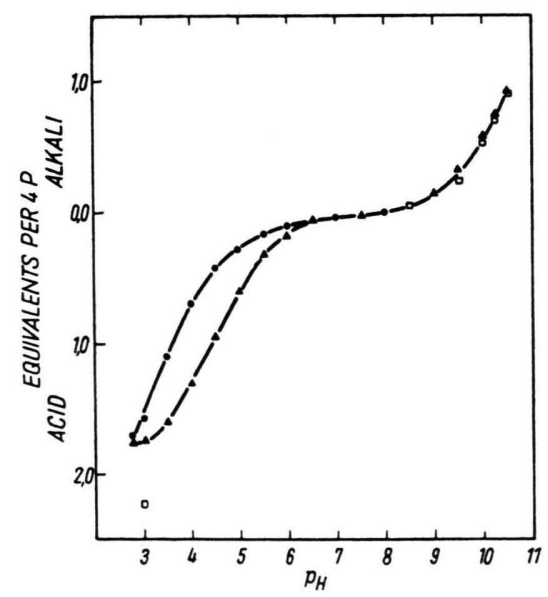

Fig. 6. Titration of liver-rRNA in $3.3 \mathrm{mM} \mathrm{MgCl}{ }_{2}$-solution at $20^{\circ}$. $, \boldsymbol{\Delta}, \square$ as in fig. $1(2 / 4)$. liver $\mathrm{RNA}$ in $\mathrm{MgCl}_{2}$ solution are represented in figure 6 . The shape of the titration pattern is largely consistent with that obtained in the presence of monovalent cations; a marked shift, however, particularly of the acid branch towards lower $p_{\mathrm{H}}$ values, is quite evident. The value obtained for the $50 \%$-dissociation of the $\mathrm{N}^{1}=\mathrm{C}^{6}-\mathrm{NH}_{2}$ and $\mathrm{N}^{3}-\mathrm{C}^{2}-\mathrm{NH}_{2}$ groups was found to be 3.57 indicating a displacement by about $-0.8 p_{\mathrm{H}}$ units compared with itration values obtained in the presence of $\mathrm{Na}^{\oplus}$ of the same ionic strength (table 2). Similarly, the degree of hysteresis is much greater than that found on titration in $0.01 \mathrm{M}$ sodium chloride; at $p_{\mathrm{H}} 4$ the difference between forward- and back-titration in $3.3 \times 10^{-3} \mathrm{M} \mathrm{MgCl}_{2}$ solution is 0.6 equivalents per 4. $\mathrm{P}$-gramatoms. In the presence of $\mathrm{Mg}$ ions no difference in the titration properties of ribosomal RNA

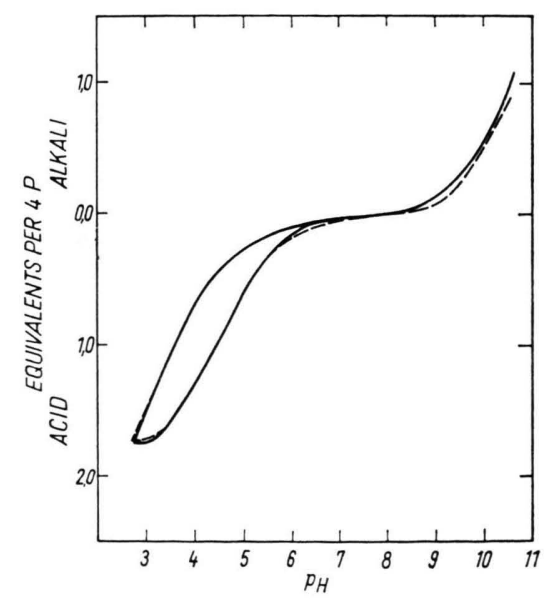

Fig. 7. Comparison of the titrations of RNA from liver ( $\longrightarrow$ ) and hepatoma $(---)$ at $20^{\circ}$ in $3.3 \mathrm{mM} \mathrm{MgCl}$-solution. 
from liver and hepatoma was observed (figure 7). In comparing the titration curves for ribosomal RNA derived in the presence of monovalent and bivalent cations of equal ionic strength $(\mu=0.01)$ it will be noticed that less equivalents of acid are bound on forward-titration with acid in the presence of $\mathrm{Mg}^{2 \oplus}(-0.58$ gram-equivalents per $4 \mathrm{P}$-gramatoms at $p_{\mathrm{H}} 4$ ) than in the presence of $\mathrm{Na}^{\oplus}$ (figure $8)$. This is also reflected by differences in $p_{\mathrm{K}}$ values. On back-titration with alkali from $p_{\mathrm{H}} 2.75$ to $p_{\mathrm{H}} 7.5$ the dissociation behaviour was found to be independent of ionic valency.
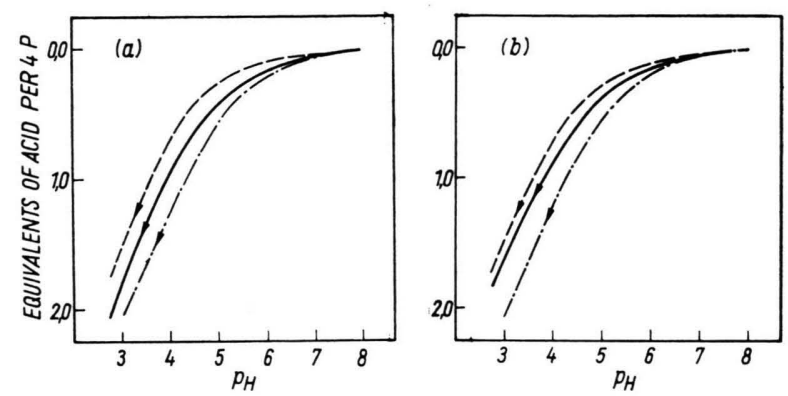

Fig. 8. Dependence of acid-base properties of RNA from liver (a) and hepatoma (b) on ion conditions at $20^{\circ}$. - $3.3 \mathrm{mM} \mathrm{MgCl}{ }_{2}, \longrightarrow 0.1 \mathrm{M} \mathrm{NaCl},-\cdot-\cdot-0.01 \mathrm{M} \mathrm{NaCl}$.

In the alkaline range no clear evidence could be provided for the dependence of the dissociation behaviour of nucleic acids upon ionic valency.

\section{Discussion}

The molecular conformation and stability of the secondary structure of nucleic acids are largely dependent upon temperature and ionic conditions. This is reflected e. g. in the sedimentation behaviour, the viscosity and the ultra-violet absorption properties of nucleic acids depending upon these factors. Increasing the temperature leads to a labilization and increasing the ionic strength to a stabilization of molecular configuration. Bivalent cations are more effective than monovalent cations.

The present results of electrometric titrations show that the acid-base properties of RNA-nucleotides are essentially dependent upon temperature and the ionic state of the solvent and, hence, upon

6 R. A. Cox and A. R. Peacocke, J. chem. Soc. [London] 1957, 4724.

7 R. A. Cox, Biochim. biophysica Acta [Amsterdam] 68, 401 [1963]. the spatial conformation of the polynucleotide. Stabilization of secondary structure brought about by a decrease in temperature or an increase in ionic strength or ionic valency leads to a change in the dissociation of the $\mathrm{N}^{1} \mathrm{H}-\mathrm{C}^{6}=\mathrm{O}, \mathrm{N}^{1}-\mathrm{C}^{6}-\mathrm{NH}_{2}$ and $\mathrm{N}^{3}-\mathrm{C}^{2}-\mathrm{NH}_{2}$ groups resulting in a displacement of $p_{\mathrm{K}}$ values towards more extreme $p_{\mathrm{H}}$ values and, consequently, in a decrease in equivalents of acid and alkali bound by nucleic acids. Changes of this kind are first and foremost attributed to the formation of H-bonds. The dependence of the dissociation properties of nucleic acids upon temperature and, hence, upon molecular conformation is different in the alkaline and acid ranges of $p_{\mathrm{H}}$. Dependence upon temperature is found to be more pronounced in the alkaline than in the acid $p_{\mathrm{H}}$ range; this may be due to the great heat of dissociation of $\mathrm{N}^{1} \mathrm{H}-\mathrm{C}^{6}=0$ groups which is higher than that of groups titratable in the acid range of $p_{\mathrm{H}}{ }^{4,6}$. Changes in hysteresis also provide certain evidence for the dependence of molecular configuration and stability upon temperature and ionic conditions. In view of the fact that the curves found on back-titrations are nearly identical under all conditions, differences in hysteresis dependent upon temperature and ionic conditions are to be assigned to differences in the behaviour of nucleic acids on forward-titration. The degree of hysteresis is found to be greatest when nucleic acids are titrated under conditions resulting in a highly ordered state of the polynucleotides so that less equivalents of acid are bound on forward-titration. A diminution in hysteresis with increasing temperature and decreasing ionic strength may thus be regarded as further evidence for the dependence of the acid-base properties of nucleobases upon the conformation of nucleic acids. At low temperatures hysteresis is probably due to rearrangements in molecular conformation in dependence upon $p_{\mathrm{H}}$. According to Cox and LitTAUER $4,7,8$ two different stable conformations of RNA may exist in the neutral and acid ranges of $p_{\mathrm{H}}$. Hysteresis in the acid $p_{\mathrm{H}}$ range is attributed to a potential energy barrier which, on forward- and back-titration, prevents the thermodynamic equilibrium of the two ordered forms of RNA from being attained spontaneously. In view of the fact that no

8 R. A. Cox, Biochim. biophysica Acta [Amsterdam] 72, 203 [1963]. 
hysteresis is observed at $50^{\circ}$ it may be inferred that at higher temperatures conversion of RNA into another molecular conformation will already take place at about neutral $p_{\mathrm{H}}$ whereas at lower temperatures it will be achieved only at higher concentrations of $\mathrm{H}^{\oplus}$. It seems to be evident that above a definite temperature there is no energy barrier which prevents thermodynamic equilibrium between two structural states of RNA from being attained.

Changes in the titration behaviour in dependence upon ionic strength are less pronounced in the alkaline $p_{\mathrm{H}}$-range compared with those in the acid range. The dependence of the acid-base properties of nucleobases of RNA upon ionic strength is essentially due to an increase in the electrostatic energy of the phosphate group brought about by a decrease in cationic strength. This exerts a direct effect on the $p_{\mathrm{K}}$ values of dissociable groups in the bases shifting them towards higher $p_{\mathrm{H}}$ values. Furthermore intramolecular $\mathrm{H}$-bonds are disrupted by breaking the bond energy and this, in turn, leads to a displacement of the $p_{\mathrm{K}}$ values of dissociable groups involved in $\mathrm{H}$-bonding. For $\mathrm{N}^{1}=\mathrm{C}^{6}-\mathrm{NH}_{2}$ and $\mathrm{N}^{3}-\mathrm{C}^{2}-\mathrm{NH}_{2}$ groups the two effects re-inforce each other in the acid $p_{\mathrm{H}}$ range while in the alkaline range the two effects are superimposed i. e. a decrease in $p_{\mathrm{K}}$ values is observed if $\mathrm{H}$-bridges are split whereas an increase in the $p_{\mathrm{K}}$ value of the $\mathrm{N}^{1} \mathrm{H}-\mathrm{C}^{6}=\mathrm{O}$ group is noticed if the negative charge of the phosphate group rises. Thus, displacement of the titration curve with ionic strength is found to be less pronounced in the alkaline and more pronounced in the acid range of $p_{\mathrm{H}}$.

The observed data on the dependence of acidbase properties of nucleic acids upon temperature and strength of monovalent cations are in accord with experiments of Cox and Littauer on RNA from $E$ coli $^{4}$, studies of $\mathrm{Cox}^{7}$ and Steiner and Beers ${ }^{9}$ on poly- $(\mathrm{A}+\mathrm{U})$, studies of Peacocke and Lifson $^{10}$ and Cox and Peacocke ${ }^{6}$ on denatured NaDNA and investigations of FrEsco and KLEMPERER ${ }^{11}$ on poly-A.

Moreover, particular mention should be made of titration experiments in the presence of $\mathrm{Mg}$ ions. $\mathrm{Mg}^{2 \oplus}$ exerts a much more pronounced stabilizing ef-

9 R. F. Steiner and R. F. Beers, Biochim. biophysica Acta [Amsterdam] 33, 470 [1959].

10 A. R. Peacocke and S. Lifson, Biochim. biophysica Acta [Amsterdam] 22, 191 [1956].

11 J. R. Fresco and E. Klemperer, Ann. N. Y. Acad. Sci. 81, 730 [1959]. fect on molecular conformation than monovalent cations of the same ionic strength. In the acid range of $p_{\mathrm{H}}$ the same degree of dissociation is attained at considerably lower $p_{\mathrm{H}}$ values; a particularly large degree of hysteresis is found on back-titration (the difference between forward- and back-titration amounting to as much as 0.6 gram-equivalente per 4. P-gramatoms). The results of titrations in the presence of $\mathrm{Mg}$ ions may be regarded as further indication of the fact that the particularly strong stabilizing effect of bivalent ions upon nucleic acids is brought about by the additional formation of chelate bonds since Cotron and Harris ${ }^{12}$ have found that chelate bonds account for a marked displacement of the $p_{\mathrm{K}}$ values of amines towards lower $p_{\mathrm{H}}$ values. In the case of nucleobases an interaction of $\mathrm{Mg}^{2 \oplus}$ with the lone-pair electrons of $\mathrm{N}$ ond $\mathrm{O}$ atoms of dissociable groups must be assumed. In view of the behaviour of RNA on forward- and back-titration in the presence of $\mathrm{Mg}$ ions it can be inferred that on titration with acid the chelate bonds are disrupted but form again on back-titration at about $p_{\mathrm{H}} 5$. Essentially, this is in accord with observations by Banarjee and Perkins ${ }^{13}$ who found that the bonding capacity of RNA for bivalent cations increases between $p_{\mathrm{H}} 3.5-4.8$ and remains constant afterwards. On back-titration below $p_{\mathrm{H}} 5$ the molecular conformation and stability of RNA and structural rearrangements would then be solely accounted for by ionic strength and not, additionally, by ionic valency which seems to be of importance only at $p_{\mathrm{H}}>5$.

On comparing the titration curves of RNA from liver and hepatoma found at different temperatures and different ionic strengths it can be seen that in RNA from hepatoma fewer base residues are ionized at a given acidic or alkaline $p_{\mathrm{H}}$ value. With increasing temperature the difference is diminished and is increased with a rise in ionic strength. Consequently, at low temperatures and higher ionic strength the $p_{\mathrm{K}}$ values of the $\mathrm{N}^{1}=\mathrm{C}^{6}-\mathrm{NH}_{2}$ and $\mathrm{N}^{3}-\mathrm{C}^{2}-\mathrm{NH}_{2}$ groups of hepatoma RNA are displaced towards lower $p_{\mathrm{H}}$ values. In view of the dependence of the dissociation properties of bases upon the conformation of nucleic acids described above the lower

12 F. A. Cotton and F. E. Harris, J. physic. Chem. 59, 1203 [1955].

13 K. C. Banarjee and D. J. Perkins, Biochim. biophysica Acta [Amsterdam] 61, 1 [1962]. 
degree of dissociation of ionizable groups in hepatoma RNA may also provide further evidence for an increased stability of the molecular conformation of ribosomal RNA from hepatoma. The present results suggest that the increase in structural stability is particularly due to the $\mathrm{NH}_{2}$ groups. It may be assumed in this connection that, apart from being involved in $\mathrm{H}$-bonding, the $\mathrm{N}^{1}=\mathrm{C}^{6}-\mathrm{NH}_{2}$ groups are also linked up with other bonds in the RNA molecule. This is in agreement with previous studies on formaldehyde reacting with ribosomal $\mathrm{RNA}^{\mathbf{1}}$; these studies show that the proportion of $\mathrm{NH}_{2}$ groups of ribosomal hepatoma RNA reacting with formaldehyde is less than that of ribosomal liver RNA.

We are grateful to Dr. R. A. Cox, National Institute for Medical Research, London, for his interest and helpful discussions.

\title{
Untersuchungen zum endogenen Stoffwechsel von Mykobakterien *
}

\author{
I. Mitt. Zur Trennung phosphorylierter Metabolite der säurelöslichen Fraktion

\section{H. ReUtGen und H. IwainsKy} \\ Forschungsinstitut für Tuberkulose und Lungenkrankheiten Berlin-Buch \\ (Direktor: Prof. Dr. med. habil. P. STeinBrück) \\ (Z. Naturforschg. 22 b, 1043-1050 [1967] ; eingegangen am 31. Dezember 1966)
}

1. Bei Untersuchungen des endogenen Stoffwechsels von Mykobakterien wird mit Hilfe eines kombinierten $\mathrm{Ogur}$ - R os e n-S chneider-Trennungsganges die säurelösliche Fraktion von Myc. smegmatis isoliert und zur Ionenaustausch-Chromatographie vorbereitet.

2. Als Anionenaustauscher wird Wofatit SBW verwendet und die Trennung mittels GradientenElution bei geschlossener Mischkammer durchgeführt. Gute Trennungen werden bei Einsatz eines zu Beginn mit sehr flachem Säure- und Neutralsalzgradienten arbeitenden Elutionssystems erreicht.

3. Durch automatische Messung der ${ }^{32} \mathrm{P}$-Aktivität und durch eine spektrophotometrische Messung der erhaltenen Fraktionen wird die Auftrennung kontrolliert.

4. Die erhaltenen Banden werden mit Hilfe der Papierchromatographie weiter aufgetrennt und auf die Anwesenheit von Monosacchariden und Aminosäuren geprüft.

5. Folgende Daten dienen zur Identifizierung der aufgetrennten Metabolite: Elutionsfolge, $R_{f}$ Werte, ${ }^{32} \mathrm{P}$-Aktivität, spektrophotometrische Auswertung bei saurer und alkalischer Reaktion vor und nach Hydrolyse. In besonderen Fällen werden spezielle Methoden, z. B. Cyanid-Komplex bei NAD bzw. NADP, zur Erhärtung der Aussage herangezogen.

6. Neben den energiereichen Phosphaten und den Phosphorsäureestern der E m b d e n M e y e r h of - Kette werden in den Zellen von Myc. smegmatis alle niedermolekularen Vertreter des Nucleinsäurepools nachgewiesen.

7. Die ${ }^{32} \mathrm{P}$-Verteilung kann sowohl aus der bei der Ionenaustausch-Chromatographie erhaltenen Kurve abgelesen, als auch durch quantitative Bestimmung des ${ }^{32} \mathrm{P}$ in den einzelnen Peaks ermittelt werden.

In der vorliegenden Arbeit werden folgende Abkürzungen verwendet: $\mathrm{A}=$ Adenin, $\mathrm{AMP}=$ Adenosinmonophosphat, $\mathrm{ADP}=$ Adenosindiphosphat, $\mathrm{ATP}=$ Adenosintriphosphat, $\mathrm{C}=$ Cytosin, $\mathrm{CMP}=$ Cytidinmonophosphat, $\mathrm{CDP}=$ Cytidindiphosphat, DNS = Desoxyribonucleinsäure, FAD $=$ Flavinadenindinucleotid, G = Guanin, GMP = Guanosinmonophosphat, GDP = Guanosindiphosphat, GTP = Guanosintriphosphat, H = Hypoxanthin, IMP = Inosinmonophosphat, $\mathrm{KF}=$ Kulturfiltrat, $\mathrm{LF}=$ Lipid-Fraktion, $\mathrm{NAD}=$ Nikotinamidadenindinucleotid, NADP $=$ Nikotinamidadenindinucleotidphosphat, $\mathrm{NS}=$ NucleinsäureFraktion, RNS = Ribonucleinsäure, SF = säurelösliche Fraktion, TCE $=$ Trichloressigsäure, $\mathrm{U}=$ Uracil, UMP $=$

* Auszugsweise vorgetragen auf dem 2. Internationalen Symposium über „Die Anwendung radioaktiver Isotope in der Tuberkulose-Forschung“ im Forschungsinstitut Borstel am 1. und 2. 10. 1965 und auf der 18. Internationalen Tuberkulosekonferenz vom 5. bis 9. 10. 1965 in München.
Uridinmonophosphat, UDP $=$ Uridindiphosphat, UTP $=$ Uridintriphosphat.

Stoffwechseluntersuchungen an proliferierenden Mykobakterien sind aus verschiedenen Gründen schwierig durchzuführen. Selbst die beim Einsatz radioaktiver Verbindungen zu erwartenden Vorteile lassen sich nur in begrenztem Ausmaß ausnutzen 1, 2. Bei Untersuchungen unter Bedingungen des endogenen Stoffwechsels entfallen viele methodisch bedingten Probleme, so daß es aussichtsreich erscheint,

1 H. Imainsky u. H. Reutgen, Z. Naturforschg. 22 b, im Druck.

2 H. Imainsky u. H. Reutgen, Rozhl. Tuberk. XXIV, 7, 459 [1964].

3 H. Reutgen, Inaug. Diss. Math.-Naturwis. Fak. HumboldtUniversität, Berlin 1965. 